\title{
Several fibroblast growth factors are expressed during pre-attachment bovine conceptus development and regulate interferon-tau expression from trophectoderm
}

\author{
Flavia N T Cooke, Kathleen A Pennington, Qien Yang and Alan D Ealy \\ Department of Animal Sciences, University of Florida, PO Box 110910, Gainesville, Florida 32611, USA
}

Correspondence should be addressed to A D Ealy; Email: ealy@ufl.edu

\begin{abstract}
The trophectoderm-derived factor interferon tau (IFNT) maintains the uterus in a pregnancy-receptive state in cattle and sheep. Fibroblast growth factors (FGFs) are implicated in regulating IFNT expression and potentially other critical events associated with early conceptus development in cattle. The overall objectives of this work were to identify the various FGFs and FGF receptors (FGFRs) expressed in elongating pre-attachment bovine conceptuses and determine if these FGFs regulate conceptus development and/or mediate IFNT production. In vitro-derived bovine blastocysts and in vivo-derived elongated conceptuses collected at day 17 of pregnancy express at least four $F G F R$ subtypes $(R 1 c, R 2 b, R 3 c, R 4)$. In addition, transcripts for $F G F 1,2$, and 10 but not $F G F 7$ are present in elongated bovine conceptuses. The expression pattern of FGF10 most closely resembled that of IFNT, with both transcripts remaining low in day 8 and day 11 conceptuses and increasing substantially in day 14 and day 17 conceptuses. Supplementation with recombinant FGF1, 2 or 10 increased IFNT mRNA levels in bovine trophectoderm cells and bovine blastocysts and increased IFNT protein concentrations in trophectoderm-conditioned medium. Blastocyst development was not affected by any of the FGFs. In summary, at least four FGFRs reside in pre- and peri-attachment bovine conceptuses. Moreover, conceptuses express at least three candidate FGFs during elongation, the time of peak IFNT expression. These findings provide new insight for how conceptus-derived factors such as FGF1, 2, and 10 may control IFNT expression during early pregnancy in cattle.

Reproduction (2009) 137 259-269
\end{abstract}

\section{Introduction}

In cattle, sheep, and presumably other ruminants, the trophectoderm-derived factor, interferon-tau (IFNT), is responsible for sustaining a pregnant state by restricting the pulsatile release of prostaglandin F2 $\alpha$ from the endometrial epithelium and thereby preventing regression of corpus luteum and return to estrus (Demmers et al. 2001, Spencer et al. 2004). IFNT also controls the expression of several uterine-derived factors that prepare the uterus for placental attachment, modifies the uterine immune system, and regulates early conceptus development (Austin et al. 1996, Teixeira et al. 1997, Ott et al. 1998, Spencer et al. 1998, Pru et al. 2001, Wang \& Goff 2002, Gifford et al. 2008). It is not surprising, therefore, that insufficient production of IFNT or failure of the maternal system to recognize this signal leads to pregnancy failures in cattle (Roberts 1991, Thatcher et al. 1994, 2001, Inskeep \& Dailey 2005).

Bovine embryo production of IFNT begins at the late morula and early blastocyst stage as the trophoblast cell lineage first develops (day 6-7 of pregnancy; Hernandez-Ledezma et al. 1992, Kubisch et al. 1998). In cattle,
IFNT mRNA levels peak around days 14-16 of pregnancy and remain elevated until implantation occurs around days 19-21 of pregnancy (Ealy et al. 2001, Mann et al. 2006, Robinson et al. 2006). A few selective uterine- and conceptus-derived factors are known regulators of IFNT expression (Roberts et al. 2003, 2004). One of these is fibroblast growth factor 2 (FGF2). FGF2 is expressed by the luminal and glandular epithelium and detected in the uterine lumen of cows and ewes throughout the estrous cycle and early pregnancy (Michael et al. 2006, Ocon-Grove et al. 2008). Studies using a bovine trophectoderm cell line (CT1) and in vitro-produced (IVP) bovine blastocysts reveal that supplementation with FGF2 increases IFNT mRNA and protein levels (Michael et al. 2006, Rodina et al. 2008).

FGF2, also known as basic FGF, was the first identified member of what is now a large family of FGFs. At least 22 genes encode multiple FGFs in the human and mouse, and their protein products contain a variety of biological activities in tissues and organs (Powers et al. 2000, Itoh \& Ornitz 2004, 2008). These FGFs interact with a group of tyrosine kinase receptors known as FGF receptors, or FGFRs. Four genes encode these receptors 
(FGFR1-4), and alternative splicing in extracellular regions generates a variety of receptor isotypes (Powers et al. 2000, Kim et al. 2001, Sleeman et al. 2001, Bottcher \& Niehrs 2005). One of these splicing events occurs within the third immunoglobulin (Ig)-like domains of FGFR1-3, where splicing one or two exons from the coding transcript generates receptors subtypes termed IgIIIb and IgIllc. These spliced variants recognize different ligands (Johnson et al. 1991, Werner et al. 1992, Powers et al. 2000). For example, the Iglllb form of FGFR2 (R2b) interacts primarily with FGF1, $3,7,10$, and 22 whereas the IgIllc form (R2c) interacts with FGF1, 2, 4, 6, and 9 (Powers et al. 2000, Itoh \& Ornitz 2004).

Several FGFs and FGFRs are associated with early conceptus development in mammals. FGF2 increases trophectoderm outgrowth size in mice and stimulates gastrulation in rabbit conceptuses (Haimovici et al. 1991, Hrabe et al. 1995, Taniguchi et al. 1998). In the pig, uterine-derived FGF7 acting through its receptor, $\mathrm{R} 2 \mathrm{~b}$, stimulates trophectoderm proliferation (Ka et al. 2001). In mice, FGF4-induced activation of its receptor partner, R2c, is critical for maintaining a trophoblast stem cell lineage that supports normal placental development (Feldman et al. 1995, Arman et al. 1998). FGF4 supplementation is required to prevent mouse trophoblast cell differentiation during culture (Tanaka et al. 1998, Hughes et al. 2004). This type of supplementation is not needed to maintain bovine trophectoderm in culture. They continue to proliferate without differentiating for extensive periods in culture (Talbot et al. 2000, 2007, Kubisch et al. 2001, Shimada et al. 2001).

Bovine and ovine conceptuses produce multiple FGFs. Transcripts for FGF2 and several FGFR spliced variants are detected in elongated ovine conceptuses (Ocon-Grove et al. 2008). Also, transcripts for FGF1, 2, 7 , and 10 and several FGFRs exist in post-attachment stage placentae in sheep and cattle (Chen et al. 2000, Pfarrer et al. 2006). These FGFs likely facilitate placental development in a variety of ways throughout gestation. This laboratory is specifically interested in uncovering the actions of these FGFs as bovine conceptuses develop and begin to attach to the uterine lining early in pregnancy. The overall objectives of this work were to identify the various FGFs and FGFRs expressed in elongating pre-attachment bovine conceptuses and determine if these FGFs contain the ability to regulate conceptus development and/or mediate IFNT production during pre-attachment development.

\section{Results}

\section{FGFR subtype expression in bovine conceptuses}

End-point RT-PCR was used to detect the FGFR isotypes expressed during early conceptus development in cattle. FGFR1, 2, 3, and 4 mRNA were detected in bovine conceptuses collected at day 17 post-insemination (Figs 1 and 2) and IVP-blastocysts (Fig. 2). Each FGFR was also detected in CT1 cells (Fig. 1), a bovine trophectoderm cell line derived from a bovine blastocyst that produces IFNT (Talbot et al. 2000, Michael et al. 2006). Amplified products of the correct size were detected in all samples with the exception of one day 17 conceptus sample that consistently lacked an FGFR1 amplicon (Fig. 1).

Primers used to amplify each FGFR spanned the sequence encoding their third Ig-like domains, and the specific spliced variant forms of FGFR1, 2, and 3 expressed by conceptuses and CT1 cells were determined by sequencing amplified products (Ocon-Grove et al. 2008). All of the FGFR1 cDNAs derived from blastocysts and day 17 conceptuses $(n=8$ clones sequenced) had the same sequence and comparative sequence analysis indicated that this sequence encoded R1C (Johnson et al. 1991, Ocon-Grove et al. 2008; GenelD: 281768; GenBank \#NP_001103677). All blastocyst- and conceptus-derived FGFR2 cDNAs ( $n=10$ clones sequenced) were identical and their translated product represented $R 2 b$, which is also known as keratinocyte growth factor (KGF)/FGF7 receptor (Johnson et al. 1991, Ocon-Grove et al. 2008;

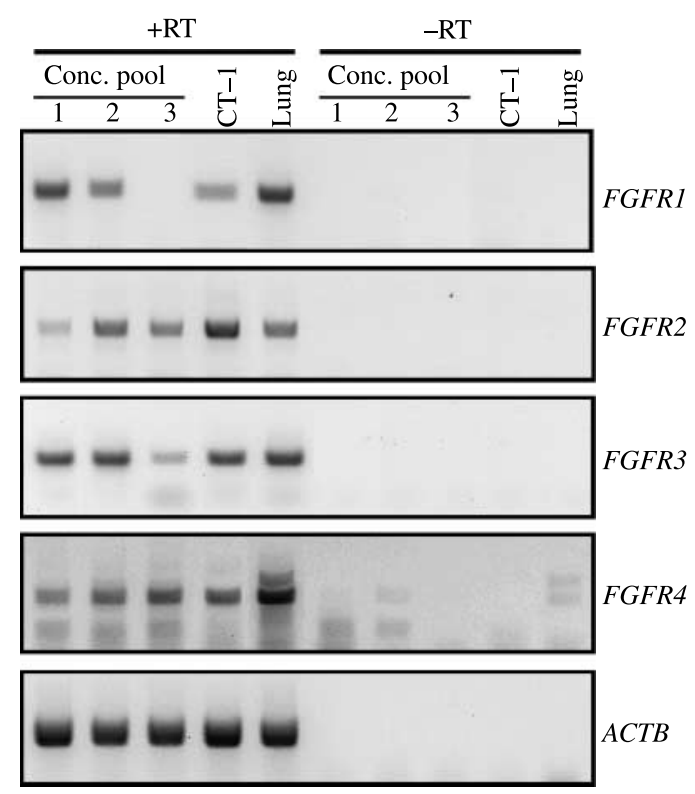

Figure 1 FGFR subtypes expressed in day 17 bovine conceptuses and CT1 cells. RT-PCR was completed on tcRNA samples derived from three pools of day 17 bovine conceptuses ( $n=3-5$ conceptuses/pool) and one CT1 sample using primers specific for the third Ig-like extracellular domain of bovine FGFR1, 2, 3, and 4 (Supplementary Table 1). Products were electrophoresed and visualized with ethidium bromide and u.v. light. tcRNA derived from bovine lung was included as a positive tissue control. Primers for $\beta$-actin $(A C T B)$ were used as a positive RT-PCR control. tcRNA not exposed to reverse transcriptase (-RT samples) was included to verify that amplified products did not result from genomic contamination. Amplified products were sequenced to verify that they represent specific FGFRs. 
GenelD: 404193; GenBank \#XP_001789758). For FGFR3, translated products for all cDNAs ( $n=10$ clones sequenced) matched the inferred amino acid sequence of R3C (GenelD: 281769; GenBank \#AAK54132; Ocon-Grove et al. 2008). FGFR4 amplicons of the correct anticipated size ( $n=4$ cDNAs sequenced) were identical to $R 4$ (GenelD: 317696). The less abundant amplicons seen in some of the FGFR4 reactions were not sequenced (Figs 1 and 2). DNA sequencing also confirmed that CT1 cells express R1C, $R 2 b, R 3 c$, and $R 4$.

\section{Expression and abundance of FGF1, 2, 7, and 10 in bovine conceptuses}

End-point RT-PCR also was used to determine if FGF1, 2,7 , and 10 are expressed in day 17 bovine conceptuses (Fig. 3). Transcripts for FGF1, 2, and 10 were detected in all three day 17 bovine conceptus RNA samples were examined. FGF1 and 2 transcripts but not FGF10 also were detected in CT1 cell RNA. FGF7 was not amplified in day 17 conceptus and CT1 samples but was detected in control samples (endometrium and lung). Bovine endometrium was included as a positive control based on previous work describing endometrial $F G F 1,2,7$, and 10 expression in cyclic and

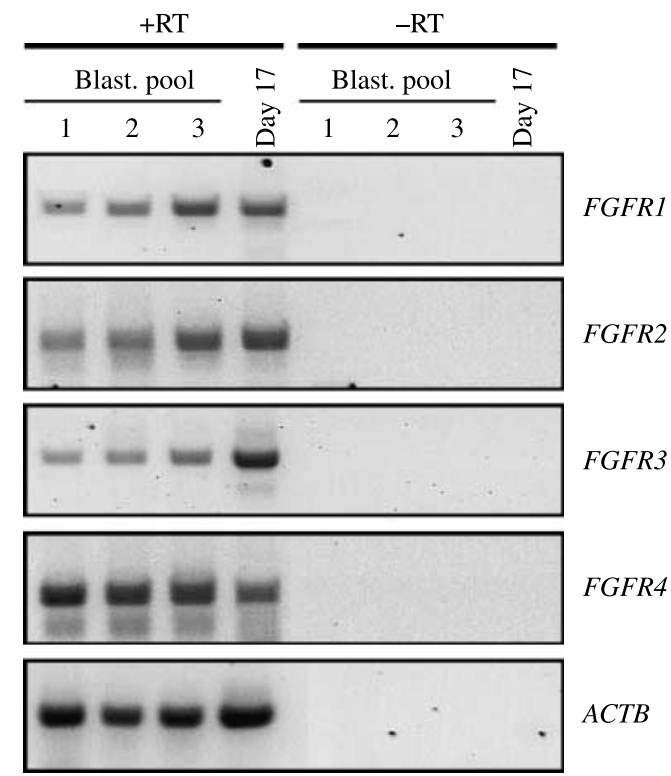

Figure 2 FGFR subtypes expressed in bovine IVP-blastocysts. RT-PCR was completed on tcRNA samples derived from three pools of IVPblastocysts ( $n=10-18$ blastocysts/pool) using primers specific for the third Ig-like extracellular domain of bovine FGFR1, 2, 3, and 4 (Supplementary Table 1). Products were electrophoresed and visualized with ethidium bromide and u.v. light. tcRNA derived from a pooled day 17 bovine conceptus preparation was included as a positive tissue control. Primers for ACTB were used as a positive RT-PCR control. tcRNA not exposed to reverse transcriptase ( - RT samples) was included to verify that amplified products did not result from genomic contamination.

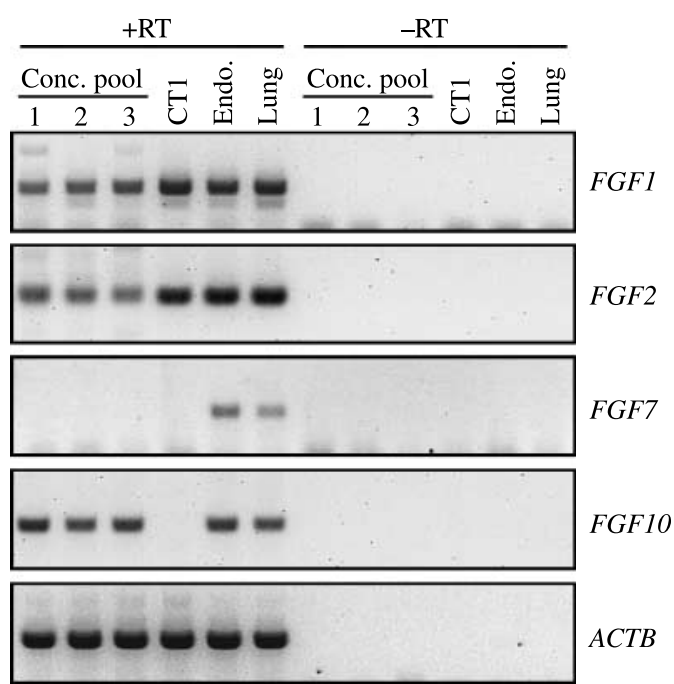

Figure 3 Expression of $F G F 1,2,7$, and 10 mRNA in day 17 bovine conceptuses. RT-PCR was completed on tcRNA from three pools of day 17 bovine conceptuses ( $n=3-5$ conceptuses/pool) and one CT1 sample with primers specific for bovine FGF1, 2, 7, and 10 (Supplementary Table 1). Products were electrophoresed and visualized with ethidium bromide and u.v. light. tcRNA from bovine endometrium and lung were included as positive controls. Primers for ACTB were used as a positive RT-PCR control. tcRNA not exposed to reverse transcriptase ( - RT samples) was included to verify that amplified products did not result from genomic contamination. Amplified products were sequenced to verify specificity of amplification.

pregnant cows and ewes (Chen et al. 2000, Pfarrer et al. 2006, Michael et al. 2006, Ocon-Grove et al. 2008). DNA sequencing verified that each PCR product represented the FGFs of interest (data not shown). Smaller, less intense PCR products were observed in some of the FGF1 reactions (Fig. 3). These products were not sequenced, and this secondary product was not detected when new primers were designed and used for qRT-PCR (see below).

The relative abundance of FGF1, 2, and 10 mRNA populations throughout pre- and peri-attachment conceptus development was determined with qRT-PCR. The internal RNA loading control, $18 S$ RNA, could not be used to normalize FGF mRNA in this study since its concentrations varied depending on the stage of conceptus development (Table 1). More specifically, concentrations of $18 S$ RNA in tcRNA increased $(P<0.05)$ as conceptuses progressed from blastocysts to elongated, filamentous conceptuses. Due to this outcome, the amount of tcRNA in each reaction was used to adjust $F G F$ values across these developmental stages (Table 1). FGF1 mRNA was not detected in IVPblastocysts. Its relative abundance remained low in conceptuses collected on days 11 and 14 of pregnancy and increased $(P<0.05)$ in day 17 conceptuses. FGF2 mRNA was detected at all stages of conceptus 
Table 1 Relative concentrations of FGF and IFNT mRNA in bovine conceptus at different stages of development.

\begin{tabular}{lcccr}
\hline Conceptus stage & FGF1 & FGF2 & FGF10 & IFNT \\
\hline Blastocyst & - & $0.037 \pm 0.024^{\mathrm{a}}$ & - & 185 \\
d11 & $0.008 \pm 0.004^{\mathrm{a}}$ & $0.074 \pm 0.024^{\mathrm{ab}}$ & $0.122 \pm 0.054^{\mathrm{a}}$ & $0.010 \pm 0.0009^{\mathrm{a}}$ \\
d14 & $0.003 \pm 0.001^{\mathrm{a}}$ & $0.158 \pm 0.055^{\mathrm{b}}$ & $1.02 \pm 0.37^{\mathrm{ab}}$ & $0.04 \pm 0.02^{\mathrm{a}}$ \\
d17 & $0.94 \pm 0.34^{\mathrm{b}}$ & $0.096 \pm 0.023^{\mathrm{b}}$ & $2.61 \pm 0.87^{\mathrm{b}}$ & $0.33 \pm 0.15^{\mathrm{b}}$ \\
\hline
\end{tabular}

Different superscripts represent differences in relative abundance of mRNA species within each column $(P<0.05)$.

development, and concentrations were greater $(P<0.05)$ in day 14 and 17 conceptuses than in day 8 IVPblastocysts. Day 11 conceptuses contained intermediate amounts of FGF2 mRNA. FGF10 mRNA was not detected in IVP-blastocysts and low levels were detected in day 11 conceptuses. The relative abundance of FGF10 mRNA was substantially greater $(P<0.05)$ in day 14 and 17 conceptuses. As anticipated, concentrations of IFNT mRNA were low in IVP-blastocysts and day 11 conceptuses and then increased $(P<0.05)$ in day 14 conceptuses and then again in day 17 conceptuses $(P<0.05)$.

A separate analysis was used to describe the relative abundance of $F G F 1,2$, and 10 mRNA within each stage of bovine conceptus development (Fig. 4). Relative abundance of $18 S$ RNA was used to normalize FGF values within each stage of pregnancy examined. FGF2 was the only FGF transcript identified in IVP-blastocysts. It also was the most abundant FGF transcript in day 11 conceptuses. In day 14 conceptuses, FGF2 and 10 mRNA were present at similar levels. By comparison, FGF1 mRNA abundance was low $(P<0.05)$ in day 11 and 14 conceptuses. FGF10 was the most prevalent transcript in day 17 conceptuses, where it represented $\sim 85 \%$ of the FGF transcripts among the three specific FGFs examined in these conceptuses.

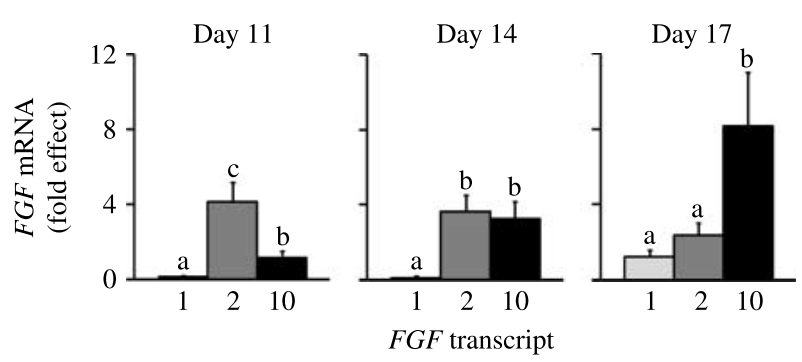

Figure 4 Expression profiles of $F G F 1,2$, and 10 during bovine conceptus development. TcRNA was extracted from bovine conceptuses collected on days 11,14 , and 17 post-insemination $(n=5$ pools/stage of development; $2-5$ conceptuses/pool). TaqMan qRT-PCR was completed using primers/probes specific for boFGF1, 2, and 10 (Supplementary Table 3). Abundance of $18 S$ RNA was used as an internal control to normalize $F G F$ values within each stage of development. $\Delta C_{\mathrm{t}}$ values were used to analyze the data within each stage of development and data are presented as mean folddifferences \pm S.E.M. from the lowest expression value within each stage. Different superscripts represent treatment differences within each stage of development $(P<0.05)$.

\section{Biological activity of FGF1, 2, and 10 on bovine trophectoderm and IVP-blastocysts}

The ability of these conceptus-derived FGFs to stimulate IFNT production was first examined using CT1 cells. A dose-responsive increase in both IFNT mRNA (Fig. 5A) and protein (Fig. 5B) concentrations were observed after incubating CT1 cells in medium containing commercially available rbFGF1, rbFGF2, and rhFGF10. rbFGF1 and 2 were better than rhFGF10 at increasing $(P<0.05)$ IFNT mRNA abundance, (5-50 ng/ml versus $500 \mathrm{ng} / \mathrm{ml})$. No such disparities in effective doses among FGF preparations were observed when IFNT protein
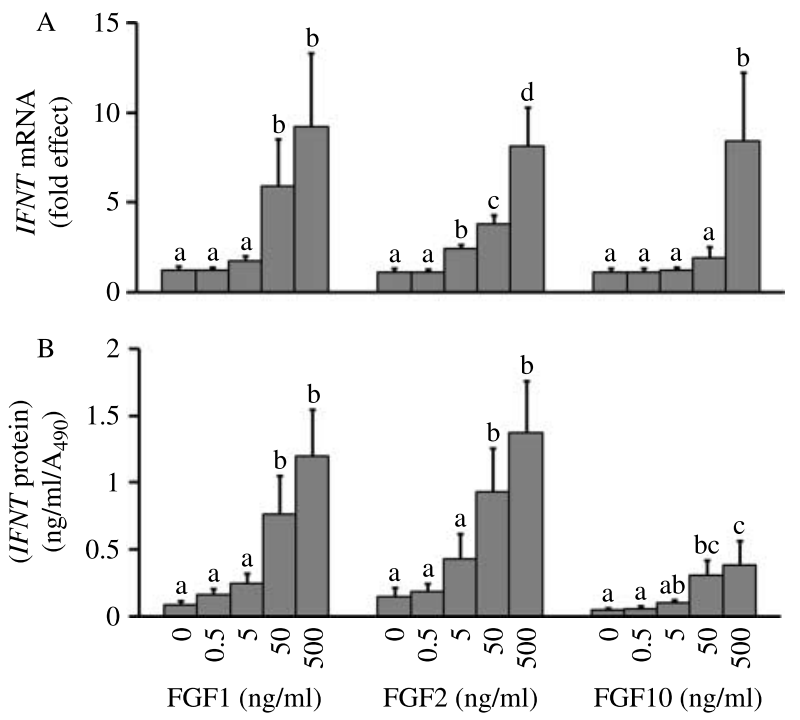

Figure 5 Increase in the relative abundance of IFNT mRNA and biologically activity of IFNT in conditioned medium after FGF1, 2, and 10 treatments. CT1 cells were incubated in medium containing $0,0.5$, 5, 50, or $500 \mathrm{ng} / \mathrm{ml}$ of rbFGF1, rbFGF2, or rhFGF10. A: After $24 \mathrm{~h}$, tcRNA was extracted and qRT-PCR was performed to determine the relative abundance of IFNT mRNA ( $n=4$ replicate experiments; 2 wells/treatment/replicate experiment). Abundance of $18 S$ RNA was used as an internal control to normalize IFNT mRNA values. $\Delta C_{\mathrm{t}}$ values were used to analyze the data and mean fold-differences \pm s.E.M. from the lowest expression value are presented. B: After $48 \mathrm{~h}$, conditioned medium was collected and IFNT concentrations $\left(\mathrm{pg} / \mathrm{ml} / \mathrm{A}_{490}\right)$ were determined by using an antiviral assay $(n=5$ replicate experiments; 2 wells/treatment/replicate experiment). Viable CT1 cell number was determined by quantifying the amount of tetrazolium (MTS) oxidation (absorbance at $490 \mathrm{~nm}$ ). Antiviral results were adjusted accordingly. Different superscripts represent treatment differences within panels $(P<0.05)$. 
concentrations in conditioned-CT1 medium were examined. Increases $(P<0.05)$ in IFNT protein levels were evident for each recombinant preparation when supplemented at a concentration of $50 \mathrm{ng} / \mathrm{ml}$.

A study was completed to determine if rhFGF7 could influence IFNT mRNA levels in CT1 cells (data not shown). FGF7 interacts solely with R2b (Lu et al. 1999, Powers et al. 2000), thereby making it an ideal candidate for examining if this receptor subtype is involved with mediating FGF effects on IFNT expression. Provision of $5 \mathrm{ng} / \mathrm{ml}$ rhFGF7 was sufficient to increase $(P<0.05)$ IFNT mRNA abundance in CT1 cells. Exposure to larger doses of rhFGF7 (50 and $500 \mathrm{ng} / \mathrm{ml}$ ) caused further increases in IFNT mRNA concentrations.

A subsequent study was completed to determine if FGF1, 2, and 10 supplementation influences development and IFNT expression in bovine blastocysts (Fig. 6).
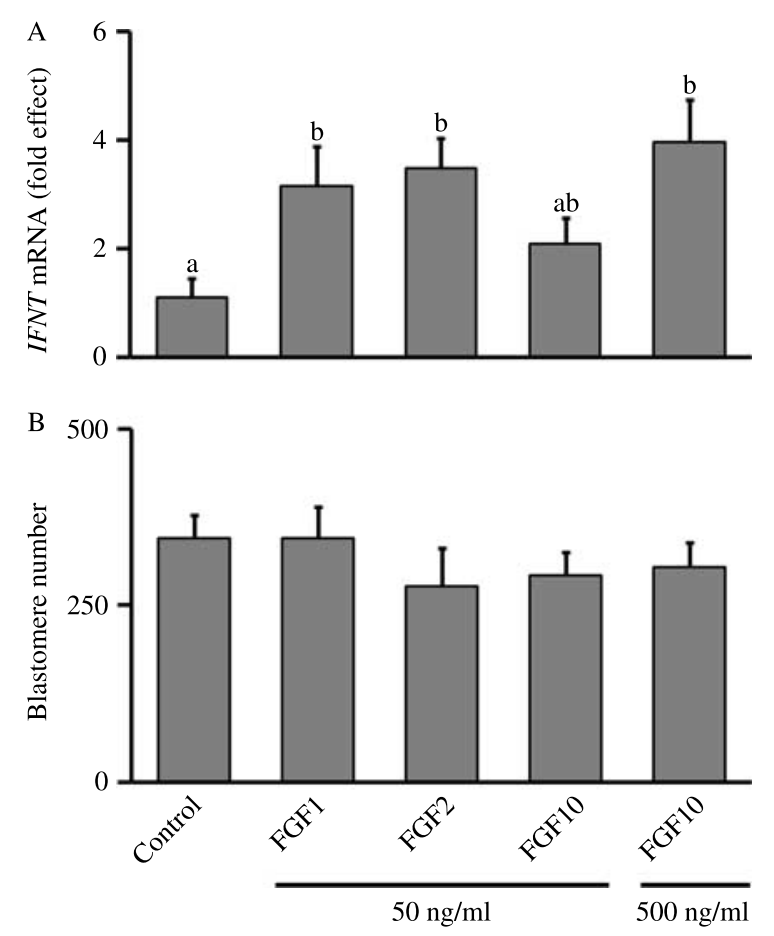

Figure 6 The effect of FGF1, 2, or 10 supplementation on IFNT mRNA concentrations and blastomere numbers in cultured bovine blastocysts. Individual IVP-blastocysts were placed in $30 \mu \mathrm{l}$ drops of medium containing rbFGF1 (50 ng/ml), rbFGF2 (50 ng/ml), rhFGF10 (50 or $500 \mathrm{ng} / \mathrm{ml})$, or vehicle only $(50 \mu \mathrm{g} / \mathrm{ml} \mathrm{BSA})$ and incubated at $38.5^{\circ} \mathrm{C}$ for 24 or $48 \mathrm{~h}$. A: After $24 \mathrm{~h}$, tcRNA was extracted and qRT-PCR was performed to determine the relative abundance of IFNT mRNA ( $n=14-22$ blastocysts/treatment spread over four replicate experiments). Abundance of $18 S$ RNA was used as an internal control to normalize IFNT mRNA values. $\Delta C_{\mathrm{t}}$ values were used to analyze the data and mean fold-differences \pm s.E.M. from the lowest expression value are presented. B: After $48 \mathrm{~h}$, number of nuclei per blastocyst was determined after Hoechst 33342 staining and epifluorescence microscopy ( $n=22-25$ blastocysts/treatment spread over four replicate experiments). Different superscripts represent treatment differences within $(\mathrm{A})$ and $(\mathrm{B}) ; \mathrm{P}<0.05)$.
Individual IVP-blastocysts were placed in medium drops containing $50 \mathrm{ng} / \mathrm{ml} \mathrm{rbFGF1}$ or rbFGF2, 50 or $500 \mathrm{ng} / \mathrm{ml}$ rhFGF10, or no FGF treatment (control) and IFNT mRNA abundance (Fig. 6A) and blastomere numbers (Fig. 6B) were determined after 24 and $48 \mathrm{~h}$ respectively. Incubation with medium containing $50 \mathrm{ng} / \mathrm{ml}$ rbFGF1 or 2 increased $(P<0.05)$ IFNT mRNA abundance compared with the control. Blastocysts required $500 \mathrm{ng} / \mathrm{ml}$ rhFGF10 to observe this effect. Blastomere numbers, as determined by quantifying the number of stained nuclei in blastocysts after $48 \mathrm{~h}$ exposure to FGF treatment, were not affected by any of the FGF proteins at any of the doses examined.

\section{Discussion}

This laboratory previously described a role for FGF2 in stimulating IFNT production in bovine conceptuses (Michael et al. 2006, Rodina et al. 2008). Initially, the uterine epithelium was proposed as the primary site of FGF2 production in cattle (Michael et al. 2006), but work contained herein and other findings (Daniels et al. 2000, Lazzari et al. 2002, Ocon-Grove et al. 2008) establish that bovine conceptuses also produce FGF2. FGF2 mRNA is detected at the morula/blastocyst stage in this and other studies (Daniels et al. 2000, Lazzari et al. 2002), and transcript abundance increases in conceptuses undergoing elongation (days $14 \& 17$ ). Also, at least two of the primary receptor partners for FGF2, R1c, and R3c, preside in ovine conceptuses (Ornitz 2000, Powers et al. 2000, Ocon-Grove et al. 2008). An additional receptor subtype, $\mathrm{R} 2 \mathrm{~b}$, is also produced by ovine conceptuses (Chen et al. 2000, Ocon-Grove et al. 2008). FGF2 interacts with R2b with a lower affinity than R1c and R3c (Ornitz 2000, Powers et al. 2000), thereby suggesting that additional FGFs may impact conceptus development by acting through R2b.

Bovine conceptuses contain the same FGFRs as elongating ovine conceptuses (Ocon-Grove et al. 2008). In addition, this work identified the expression of $R 4$ in bovine IVP-blastocysts and elongated conceptuses. Amplifying the IgIII region for each FGFR permitted the identification of specific FGFR spliced variants $(R 1 c, R 2 b, R 3 c)$. It remains possible that additional variant forms for $R 1,2$, and 3 exist in bovine conceptuses and perhaps these subtypes could have been identified if additional cloned products were sequenced or if receptor subtype-specific primer sets were employed. That being said, verifying the presence of $R 2 b$ throughout early bovine conceptus development provided the impetus for focusing on ligands that interact with this receptor subtype. Investigating this receptor isoform was of particular interest because the $R 2 b$ and R2c subtypes are implicated in regulating trophectoderm development in other species (Feldman et al. 1995, Arman et al. 1998, Ka et al. 2001). 
The primary ligands for R2b are FGF1, 3, 7, 10, and 22 (Ornitz 2000, Powers et al. 2000). In this work, transcripts for FGF1 and 10 were detected, whereas FGF7 transcripts were absent in bovine conceptuses. Tissue-specific expression of FGF3 and 22 is highly restrictive in other species (e.g., cerebellum, retina, and inner ear for FGF3; cerebellum and skin for FGF22; Wilkinson et al. 1989, Umemori et al. 2004, Komi-Kuramochi et al. 2005). Therefore, these FGFs were not examined in this work. Transcript levels of FGF1 were low throughout bovine conceptus development, whereas FGF10 mRNA concentrations were low or non-existence on or before day 11 but were readily apparent in day 14 and 17 conceptuses. The relative amount of FGF10 mRNA rivaled that of FGF2 in day 14 conceptuses and represented to predominant FGF transcript in day 17 conceptuses. Chen et al. (2000) identified that the extraembryonic mesoderm is the primary site of FGF10 expression in ovine conceptuses. The extraembryonic mesoderm emerges from the epiblast (i.e., the gastrulating inner cell mass) around days 14-16 of pregnancy in cattle and soon thereafter extends between the trophectoderm and endoderm to establish the inner chorionic layer and the outer yolk sac layer (Betteridge \& Flechon 1988, Hue et al. 2001, Maddox-Hyttel et al. 2003, Degrelle et al. 2005, Robinson et al. 2006). Although, localization studies were not completed herein to verify the sources of FGF10 expression during conceptus elongation, our assessment of FGF10 mRNA abundance is supportive of the concept that the profound rise in FGF10 expression in day 14 and 17 conceptuses stems from the formation and expansion of extraembryonic mesoderm.

It is interesting that the ontogeny of conceptus-derived FGF10 expression resembled that of IFNT. Relative abundances for both transcripts were low in day 11 conceptuses and increased profoundly at days 14 and 17 of pregnancy. Since mesoderm formation occurs around the same time as conceptus elongation and maximal IFNT expression (Ealy et al. 2001, Mann et al. 2006, Robinson et al. 2006), it is possible that a product of this tissue, such as FGF10, could be required for maximal IFNT expression as well as other aspects of early conceptus development and elongation. Timely epiblast development certainly is linked to conceptus elongation and survival. Bovine embryos derived from IVP and nuclear transfer (NT) usually have lower survival rates than their in vivo-generated counterparts after transfer, and fewer IVP and NT embryos contain epiblasts at day 14 of pregnancy (Bertolini et al. 2002, Alexopoulos et al. 2008). Also, fewer pregnancies resulted from the transfer of day 14 bovine conceptuses containing either nonintact or undetectable epiblasts as compared with the transfer of conceptuses containing intact epiblasts (Fischer-Brown et al. 2004). Further work is needed to determine if paracrine-acting factors produced by the epiblast, and more specifically by the newly formed mesoderm, promote trophectoderm proliferation and gene expression.

Tissue localization studies were not completed in this work, but the trophectoderm is likely one site of FGF1 and 2 production in elongating conceptuses. FGF1 and 2 mRNA are detected in CT1 cells and localized to the trophectoderm of mid-gestation bovine placentae (Pfarrer et al. 2006). Likewise, each of the four FGFR subtypes identified in bovine blastocysts and elongating conceptuses probably are expressed in trophectoderm since they were detected in CT1 cells. This certainly is the case for the $R 2 b$ subtype. Its transcripts localize to ovine and bovine trophectoderm during peri- and postattachment development (Chen et al. 2000, Pfarrer et al. 2006). $R 2 b$ is also expressed by the uterine epithelium in ewes where it appears to play a central role in regulating uterine activity during pregnancy by interacting with stromal-derived FGF10 (Chen et al. 2000). It is possible, but unlikely that this uterine source for FGF10 is released into the uterine lumen. Most FGFs, including FGF10, contain high affinities for heparan sulfate proteoglycans and remain sequestered within the extracellular matrix of tissues rather than being released into the blood or luminal cavities (Ornitz 2000, Powers et al. 2000). Very little to no FGF10 is produced by luminal and glandular epithelium. Cell lines developed from ovine endometrial epithelium contain FGF10 mRNA (Chen et al. 2007), but in situ studies did not detect FGF10 transcripts in luminal or glandular epithelium during diestrus and early pregnancy (Chen et al. 2000). By contrast, FGF2 is produced by the endometrial epithelium and can be found in the uterine lumen during early pregnancy (Michael et al. 2006, Ocon-Grove et al. 2008). It remains unknown, if uterine-derived FGF1 is released into the uterine lumen. FGF1 is produced by bovine luminal epithelium during mid-gestation (Pfarrer et al. 2006) and, therefore, may have a similar uterine expression pattern as FGF2 prior to placental attachment.

All of the recombinant FGF preparations were able to stimulate IFNT mRNA and/or protein levels in bovine trophectoderm and IVP-blastocysts. FGF1 and 2 proteins were similar in their ability to stimulate IFNT mRNA, whereas as much as tenfold more FGF10 was required in some cases to elicit biological responses on trophectoderm and blastocysts. It is unclear why FGF10 contained slightly lower biological activity than other FGFs. Perhaps using a human recombinant FGF10 protein that contains a good but not great sequence identity to its bovine homolog caused this effect $(91.6 \%$ identical amino acid sequence identity to bovine FGF10). Alternatively, issues with freeze/thawing the recombinant preparation, post-thawing handling, and/or protein degradation rate during culture could have contributed to this outcome. Regardless of the reason, rhFGF10 did contain biological activity on both CT1 cells and IVP blastocysts. Therefore, its bovine homolog is probably 
also capable of stimulating IFNT expression in bovine trophectoderm.

None of the FGF proteins examined affected trophectoderm and blastomere cell numbers. Previous work consistently observed little to no mitogenic effect of boFGF2 (Michael et al. 2006, Rodina et al. 2008). One interpretation of these findings is that the FGFs under investigation are likely not serving an active role in regulating cell proliferation rate early in conceptus development. However, the ability of selective FGFs to influence early bovine embryo development (i.e., blastocyst formation, blastocyst quality, and ratio of trophoblast/inner cell mass cells) have yet to be fully explored.

It still remains unclear whether one or multiple FGFR subtypes dictate FGF responses in bovine trophectoderm. FGF1 associates equally well with each of the FGFR variants expressed in bovine conceptuses, and FGF2 has a high affinity for R1c and R3c and a moderate affinity for R2b (Ornitz 2000, Powers et al. 2000, Itoh \& Ornitz 2004). FGF10 is more selective in its receptor partner binding interactions and generally acts through either R2b or R1b (Lu et al. 1999, Powers et al. 2000). The latter receptor subtype was not detected in conceptus and CT1 screens. Recombinant FGF7was included in one CT1 study to determine if its interaction with R2b was sufficient to induce an IFNT mRNA response. FGF7 is not expressed in pre- and periattachment bovine conceptuses and endometrial sources of FGF7 are localized too deep within the stromal region to permit FGF7 from being secreted into the uterine lumen (Chen et al. 2000). However, FGF7 acts exclusively through R2b (Lu et al. 1999, Powers et al. 2000), and its ability to increase IFNT mRNA levels in CT1 cells implicates R2b as one of the receptor subtypes responsible for FGF actions on trophectoderm. This observation does not exclude the possibility that other FGFRs also may participate in directing the biological activities of other FGFs on bovine trophectoderm, but the relative importance of other FGFRs in regulating IFNT expression and other critical actions during conceptus development remains to be fully explored.

In conclusion, current findings provide new insight for how conceptus-derived factors may control IFNT expression during early pregnancy in cattle. Multiple FGFRs are expressed by elongating bovine conceptuses, and at least one of these receptor subtypes, R2b, is involved with mediating FGF-induced increases in IFNT mRNA and protein production in bovine trophectoderm. Also, several FGFs are expressed by bovine conceptuses. Of particular note is FGF10, a ligand for R2b whose expression increases in day 14 and 17 conceptuses coincident with peak IFNT expression. This and potentially other conceptus-derived FGFs as well as uterinederived FGFs likely are acting in concert to impact IFNT production from bovine trophectoderm. This could well be an essential component for the establishment and maintenance of pregnancy in cattle and sheep.

\section{Materials and Methods}

\section{Animal use and tissue collection}

All animal experimentation was completed in accordance with Institutional Animal Care and Use Guidelines and with the approval of the Institutional Animal Care and Use Committee at the University of Florida. Healthy, non-lactating Holstein cows $(n=21)$ were housed at the University of Florida Dairy Unit (Hague, FL, USA) and fed a maintenance diet. Conceptuses were harvested on days 11,14 , and 17 post-insemination after superovulation. In brief, growth of a new wave of follicles was induced by ablating large follicles $(>10 \mathrm{~mm}$ diameter) on ovaries with an ultrasound-guided follicle aspiration device (Bilby et al. 2006). A controlled drug intravaginal device containing progesterone (1.38 g; Eazi-Breed CIDR; Pfizer Corp., New York, NY, USA) was inserted after follicle ablation. Cows were provided a 4 day regiment of FSH treatment (Folltropin-V; AgTech, Manhattan, KS, USA; $400 \mathrm{mg}$ total) beginning 2 days after follicle ablation, CIDRs were removed on the third day of FSH treatment and cows were injected with Lutalyse $(25 \mathrm{mg}$ each time; Pfizer Corp.) twice on the third day of FSH treatment (Sartori et al. 2004). Superovulated cows were inseminated with Holstein semen (Genex Cooperative Inc., Shawano, WI, USA) at 12 and $24 \mathrm{~h}$ after first detection of standing estrus.

Conceptuses at day 11 and 14 post-insemination were collected non-surgically after providing an epidural injection of $2 \%$ (wt/vol) lidocaine (Sparhawk Laboratories Inc., Shawnee, Mission, KS, USA) by inserting a latex Foley catheter (Agtech Inc.) through the cervix and flushing each horn with $250-500 \mathrm{ml}$ flush solution (Dulbecco's PBS (DPBS; Invitrogen Corp., Carlsbad, CA, USA) with $0.04 \%$ BSA (BSA)). Conceptuses at day 17 post-insemination were collected during slaughter at the UF Meats Laboratory by excising reproductive tracts, injecting flush solution into the anterior tip of one uterine horn and collecting fluid and conceptuses from an excised anterior portion of the other uterine horn. Flush solutions were examined macroscopically and microscopically, if needed (day 11) to collect conceptuses. All day 11 conceptuses were ovoid in shape and most could be detected in the petri dish with the naked eye. Approximately, half of the day 14 conceptuses collected were ovoid but readily visible in the petri dish with the naked eye. The remaining day 14 conceptuses were in the initial stages of elongation and ranged from 0.5 to $3 \mathrm{~cm}$ in length. All of the day 17 conceptuses were elongated and filamentous, ranging from 5 to $45 \mathrm{~cm}$ in length. Conceptuses were pooled together in small groups ( $n=3-5 /$ pool) and snap-frozen in liquid nitrogen and stored at $-80^{\circ} \mathrm{C}$. Each pool of the day 14 samples contained a mixture of ovoid and elongating conceptuses. Additional tissues, including endometrium, lung, and brain (hippocampus and cerebrum), were collected from cows during slaughter, snap-frozen in liquid nitrogen and stored at $-80^{\circ} \mathrm{C}$ until use as positive control samples.

Total cellular (tc) RNA was extracted from day 11 and day 14 conceptus pools using the RNeasy Micro kit (Qiagen Inc, Valencia, CA, USA). The RNAqueous-Midi RNA Isolation Kit (Applied Biosystems/Ambion, Austin, TX, USA) was used to extract tcRNA from d17 conceptuses. The PureLink Microto-Midi Total RNA Purification System with Trizol (Invitrogen Corp.) was used to extract tcRNA from other tissues. 
Concentration and quality of isolated tcRNA was assessed by using a NanoDro8000 spectrophotometer (Thermo Fisher Scientific, Pittsburgh, PA, USA).

\section{Bovine in vitro embryo production}

In vitro maturation, fertilization, and cultures procedures were used to generate bovine blastocysts (Rivera \& Hansen 2001, Moreira et al. 2002, Paula-Lopes \& Hansen 2002). Briefly, oocytes from slaughterhouse derived ovaries were matured and fertilized in vitro with Holstein semen (Genex Cooperative Inc). After fertilization, presumptive zygotes were placed in groups of $25-30$ and incubated in $5 \% \mathrm{CO}_{2} / 5 \% \mathrm{O}_{2} / 90 \% \mathrm{~N}_{2}$ at $38.5{ }^{\circ} \mathrm{C}$ in $50 \mu \mathrm{l}$ drops of either synthetic oviduct fluid (SOF; Chemicon International/Millipore, Billerica, MA, USA) or modified potassium simplex optimized medium (mKSOM; Caisson Laboratories, North Logan, UT, USA), depending on the study. Both media were supplemented with $0.3 \%(\mathrm{w} / \mathrm{v})$ essentially fatty acid free BSA (Sigma Aldrich, St Louis, MO, USA). In one study, expanded and hatched blastocysts formed on day 8 postfertilization after culture in $\mathrm{mKSOM}$ were placed in groups $(n=10-18)$, snap-frozen in liquid nitrogen and stored at $-80^{\circ} \mathrm{C}$. TCRNA was extracted using the RNeasy Micro kit (Qiagen Inc.) and quantified by using a NanoDro8000 spectrophotometer (Thermo Fisher Scientific).

In a second set of studies, blastocysts identified on day 8 post-fertilization were collected and washed in DPBS containing $1 \mathrm{mg} / \mathrm{ml}$ polyvinyl pyrolidone (PVP; Thermo Fisher Scientific). Individual blastocysts were placed in $30 \mu \mathrm{l}$ drops Medium 199 (M199) containing 2.5\% (v/v) fetal bovine serum (FBS; Invitrogen Corp.) and $10 \mu \mathrm{M}$ Gentamycin (Sigma Chemical Co.; Rodina et al. 2008). The stage of blastocyst development (non-expanded or expanded) was used to balance treatment combinations. Medium was supplemented with $50 \mathrm{ng} / \mathrm{ml}$ recombinant (r) bovine (b) FGF1 (R\&D Systems), $50 \mathrm{ng} / \mathrm{ml}$ rbFGF2 (R\&D Systems Minneapolis, MN, USA), 50 or $500 \mathrm{ng} / \mathrm{ml}$ r human (h) FGF10 (Invitrogen Corp.) or carrier only (M199 containing 1\% (w/v) BSA). In one study, blastocysts were incubated at $38.5{ }^{\circ} \mathrm{C}$ in $5 \% \mathrm{CO}_{2} / 5 \% \mathrm{O}_{2} / 90 \% \mathrm{~N}_{2}$ for $24 \mathrm{~h}$, then washed once in PBS/PVP, snap-frozen in liquid nitrogen and stored at $-80{ }^{\circ} \mathrm{C}$. In a companion study, blastocysts were incubated at the aforementioned conditioned for $48 \mathrm{~h}$ then were washed once in PBS/PVP and fixed by incubation in $4 \%(\mathrm{w} / \mathrm{v})$ paraformaldehyde (Polysciences Inc., Warrington, PA, USA) for $10 \mathrm{~min}$ and processed for determining blastomere numbers with Hoechst 33342 staining and epifluorescence microscopy (Rodina et al. 2008). Number of Hoechst-positive nuclei was quantified with NIS-Elements software (Nikon Instruments Inc, Melville, NY, USA).

\section{Bovine trophectoderm cell (CT1) culture}

Cells were propagated as described previously (Talbot et al. 2000, Michael et al. 2006) in DMEM containing 10\% FBS and other supplements (4.5 g/l D-glucose, non-essential amino acids, $2 \mathrm{~mm}$ glutamine, $2 \mathrm{~mm}$ sodium pyruvate, $55 \mu \mathrm{m}$ $\beta$-mercaptoethanol, $100 \mathrm{U} / \mathrm{ml}$ penicillin G, $100 \mu \mathrm{g} / \mathrm{ml}$ streptomycin sulfate, and $250 \mathrm{ng} / \mathrm{ml}$ amphoterin B) on Matrigel Basement Membrane Matrix (BD Biosciences, Bedford, MA,
USA) at $38.5^{\circ} \mathrm{C}$ in $5 \% \mathrm{CO}_{2}$ in air. CT- 1 cells were seeded onto 12 -well plates. Upon reaching $\sim 50 \%$ confluence, fresh DMEM lacking FBS but containing all other supplements and a serum substitute (insulin/transferrin/selenium; ITS; Invitrogen Corp.) were added to cultures. After $24 \mathrm{~h}$, fresh serum-free DMEM containing $0,0.5,5,50$, or $500 \mathrm{ng} / \mathrm{ml}$ of either rbFGF1, rbFGF2, or rhFGF10 were provided to cultures ( $n=2$ wells/FGF treatment/replicate experiment). Each treatment, including controls contained $50 \mu \mathrm{g} / \mathrm{ml}$ BSA as a carrier protein. For some studies, tcRNA was extracted $24 \mathrm{~h}$ after FGF supplementation using the PureLink Micro-to-Midi Total RNA Purification System with Trizol (Invitrogen Corp.) following manufacturer's parameters $(n=4$ replicate experiments). TCRNA was stored at $-80{ }^{\circ} \mathrm{C}$ until further use.

In another study, conditioned medium was collected and stored at $-20{ }^{\circ} \mathrm{C}$ after $48 \mathrm{~h}$ exposure to FGF treatments $(n=5$ replicate experiments). Viable cell number was determined by using the Cell Titer $96 \mathrm{AQ}_{\text {ueous }}$ One Solution Cell Proliferation Assay (Promega, Madison, WI, USA). Absorbance was measured at $490 \mathrm{~nm}$. A cytopathic antiviral assay was used to determine concentrations of biologically active IFNT in conditioned medium (Roberts et al. 1989, Michael et al. 2006, Rodina et al. 2008). Unconditioned medium and FGF preparations did not contain antiviral activity. Data are expressed as $\mathrm{ng} / \mathrm{ml}$ of biologically activity bolFNT based on the specific activity of the rbIFNT preparation used as the standard $\left(8.03 \times 10^{8} \mathrm{IU} / \mathrm{mg}\right)$ and normalized by the cell proliferation assay absorbance reading to account for well to well variations in CT1 cell density.

\section{End-point RT-PCR}

All samples were incubated with RNase-free DNase (Applied Biasystems Ambion Inc.) for $30 \mathrm{~min}$ at $37^{\circ} \mathrm{C}$ then heatdenatured at $75^{\circ} \mathrm{C}$ for $10 \mathrm{~min}$ immediately before RT. The SuperScript III First,-Strand Synthesis System Kit (Invitrogen Corp.) and random hexamers were used for RT of tcRNA. Nonreverse transcribed DNase-treated RNA was included as a negative control for each sample. Gene-specific primer sets were used to amplify products for FGFR1, 2, 3, or 4 and FGF1, 2, 7, or 10 (see Supplementary Table 1, which can be viewed online at www.reproduction-online.org/supplemental/). A primer pair specific for $\beta$-actin $(A C T B)$ CDNA was included as a positive control in these reactions (Supplementary Table 1). PCR amplification was performed using either PfuUltr High-Fidelity DNA Polymerase (Stratagene) or ThermalAc DNA Polymerase (Invitrogen Corp). From 30 to 45 cycles of denaturation $\left(95^{\circ} \mathrm{C}\right.$ for $1 \mathrm{~min})$, annealing $\left(55-62{ }^{\circ} \mathrm{C}\right.$ for $1 \mathrm{~min}$; depending on the primer set) and DNA synthesis ( 72 or $74{ }^{\circ} \mathrm{C}$ for 1 min; depending on the polymerase) followed by a DNA polishing stage (72$74{ }^{\circ} \mathrm{C}$ for $10 \mathrm{~min}$ ) were completed. The presence and approximate size of amplified products were determined by electrophoresis in an agarose gel $(1.2 \%(\mathrm{w} / \mathrm{v}))$ containing ethidium bromide $(100 \mathrm{ng} / \mathrm{mL})$ and visualized on an u.v. light box.

Amplicons of the desired size were excised from gels and ligated into the pCR4-Blunt TOPO vector (Invitrogen Corp). Ligation reactions were used to transform chemically competent TOP10 E. coli (Invitrogen Corp). Selected colonies were propagated and purified clones were sequenced in both 
directions using vector primer sets at the University of Florida DNA Core Facility. Multiple clones from at least three different conceptus or CT1 samples were sequenced to verify that amplified products represented the transcript of interest. Also, DNA sequencing was used to identify specific splice variant forms of FGFR1-3 in bovine conceptuses and CT1 cells.

\section{Quantitative (q), real-time RT-PCR}

The abundance of FGFand IFNT transcripts in bovine conceptus and CT1 cells was determined by qRT-PCR. All samples were incubated with RNase-free DNase (Applied Biasystems Ambion Inc., Foster sites CA, USA) as described previously before RT with the High Capacity cDNA Archive Kit and random hexamers (Applied Biosystems Inc).

For one study with IVP-blastocysts, primers specific for bolFNT and $18 S$ (internal control; Supplementary Table 2, which can be viewed online at www.reproduction-online.org/supplemental/) were used in combination with a SybrGreen detector system (Applied Biosystems Inc.) and a 7300 Real-Time PCR System (Applied Biosystems Inc.) to quantify IFNT mRNA concentrations. After an initial activation/denaturation step $\left(50{ }^{\circ} \mathrm{C}\right.$ for $2 \mathrm{~min} ; 95^{\circ} \mathrm{C}$ for $\left.10 \mathrm{~min}\right), 40$ cycles of a two-step amplification protocol $\left(60{ }^{\circ} \mathrm{C}\right.$ for $1 \mathrm{~min}$; $95^{\circ} \mathrm{C}$ for $15 \mathrm{~s}$ ) were completed. A dissociation curve analysis $\left(60-95^{\circ} \mathrm{C}\right)$ was used to verify the amplification of a single product. Each blastocyst sample was run in duplicate reactions and a third reaction lacking exposure to reverse transcriptase was included for each sample to verify if they were free of genomic contamination. The comparative threshold cycle $\left(C_{\mathrm{t}}\right)$ method was used to quantify the abundance of IFNT mRNA relative to that of $18 S$ (Michael et al. 2006). In brief, the average $\Delta C_{\mathrm{t}}$ value for each sample was calculated $\left(I F N T C_{t}-18 S C_{t}\right)$ and used to calculate the fold-change in the relative abundance of IFNT mRNA.

A TaqMan-based qRT-PCR approach was used to quantify the abundance of FGF1, FGF2, FGF10, IFNT, and 18S RNA (internal RNA loading control) in other studies. Primers and probes specific for each FGF transcript and IFNT mRNA were synthesized (Applied Biosystems Inc.; Supplementary Table 3, which can be viewed online at www.reproduction-online.org/supplemental/) and labeled with a fluorescent $5^{\prime}$ 6-FAM reporter dye and $3^{\prime}$ TAMRA quencher. The IFNT Primer/probe set was developed to recognize every known bovine and ovine IFNT isoform (Michael et al. 2006). After an initial activation/denaturation step (50 ${ }^{\circ} \mathrm{C}$ for $2 \mathrm{~min} ; 95^{\circ} \mathrm{C}$ for $10 \mathrm{~min}$ ), 50 cycles of a two-step amplification protocol $\left(60{ }^{\circ} \mathrm{C}\right.$ for $1 \mathrm{~min} ; 95^{\circ} \mathrm{C}$ for $\left.15 \mathrm{~s}\right)$ was used with TaqMan reagent (Applied Biosystems Inc.) and a 7300 Real-Time PCR System to quantify transcript levels. Abundance of 18S RNA was determined using the 18S RNA Control Reagent Kit (Applied Biosystems Inc.) containing a 5'-VIC-labelled probe with a 3'-6-carboxy-tetramethylrhodamine quencher. Each RNA sample was analyzed in duplicate (conceptus study) or triplicate (CT1 study) reactions (10-50 ng tcRNA for blastocysts and day 11 conceptuses; 50 ng tcRNA for day 14 and 17 conceptuses and CT1 cells). An additional reaction lacking exposure to the reverse transcriptase was included for each sample to verify if they were free of genomic DNA contamination.

The $\Delta C_{\mathrm{t}}$ method was used to contrast abundance of transcripts for FGFs and IFNT relative to $18 S$ RNA in all but one study. In one study, relative amounts of $18 S$ RNA changed across stages of conceptus development, so a relative standard curve approach was used in combination with the amount of tcRNA used in qRT-PCR reactions to describe relative abundances for individual FGFs and IFNT during conceptus development (Larionov et al. 2005, Cikos et al. 2007; ABI Prism Sequence Detection System User Bulletin No. 2; Applied Biosystems Inc). One of the day 17 conceptus RNA samples was used a standard sample, and four doses of this preparation $(2,10,50,250 \mathrm{ng}$ tcRNA/reaction) was included in each realtime run. The slope and intercept for each FGF, IFNT, and $18 S$ curve was used to convert raw $C_{\mathrm{t}}$ values into values that represented the ng of control tcRNA required to equal that detected in each sample by solving the formula: $\left(10^{\left(\left(C_{t} \text { value }-y \text { intercept }\right) / \text { slope }\right)} /\right.$ sample tcRNA).

\section{Statistical analyses}

All analyses were completed by ANOVA (ANOVA) using the general linear model of the Statistical Analysis System (SAS Institute Inc, Cary, NC, USA). Differences in individual means were partitioned further by completing pair-wise comparisons (probably of difference analysis). When analyzing qRT-PCR data transformed using the $\Delta C_{\mathrm{t}}$ method, the $\Delta C_{\mathrm{t}}$ values were used for the statistical analyses but data are presented as fold differences from control values. Antiviral activity of CT1 conditioned medium was log-transformed and normalized based on predicted cell number before analysis. Results are presented as arithmetic means \pm s.E.M.S.

\section{Declaration of interest}

The authors declare that there is no conflict of interest that could be perceived as prejudicing the impartiality of the research reported.

\section{Funding}

This project was supported by National Research Initiative Competitive Grant Number 2008-35203-19106 from the USDA Cooperative State Research, Education, and Extension Service.

\section{Acknowledgements}

Authors thank Dr Jeremy Block (EmboGen, LLC) and Dr Claudia Klein (Univ. Kentucky) for assisting with flushing day 11 and 14 bovine conceptuses and Dr Daniel Sharp for assisting with collecting bovine brain samples. Authors also thank Central Packing Inc., for donating bovine ovaries used in the experiments and personnel in Dr Peter Hansen's laboratory for assistance with in vitro embryo production.

\section{References}

Alexopoulos N, Maddox-Hyttel P, Tveden-Nyborg P, D'Cruz N, Tecirlioglu T, Cooney M, Schauser K, Holland M \& French A 2008 Developmental disparity between in vitro produced and somatic cell nuclear transfer bovine days 14 and 21 embryos: implications for embryonic loss. Reproduction 136 433-445. 
Arman E, Haffner-Krausz R, Chen Y, Heath JK \& Lonai P 1998 Targeted disruption of fibroblast growth factor (FGF) receptor 2 suggests a role for FGF signaling in pregastrulation mammalian development. PNAS 95 5082-5087.

Austin KJ, Ward SK, Teixeira MG, Dean VC, Moore DW \& Hansen TR 1996 Ubiquitin cross-reactive protein is released by the bovine uterus in response to interferon during early pregnancy. Biology of Reproduction 54 600-606.

Bertolini M, Beam SW, Shim H, Bertolini LR, Moyer AL, Famula TR \& Anderson GB 2002 Growth, development, and gene expression by in vivo- and in vitro-produced day 7 and 16 bovine embryos. Molecular Reproduction and Development 63 318-328.

Betteridge KJ \& Flechon JE 1988 The anatomy and physiology of preattachment bovine embryos. Theriogenology 29 155-187.

Bilby TR, Block J, do Amaral BC, Sa Filho O, Silvestre FT, Hansen PJ, Staples CR \& Thatcher WW 2006 Effects of dietary unsaturated fatty acids on oocyte quality and follicular development in lactating dairy cows in summer. Journal of Dairy Science 89 3891-3903.

Bottcher RT \& Niehrs C 2005 Fibroblast growth factor signaling during early vertebrate development. Endocrine Reviews 26 63-77.

Chen C, Spencer TE \& Bazer FW 2000 Fibroblast growth factor-10: a stromal mediator of epithelial function in the ovine uterus. Biology of Reproduction 63 959-966.

Chen Y, Antoniou E, Liu Z, Hearne LB \& Roberts RM 2007 A microarray analysis for genes regulated by interferon- $\tau$ in ovine luminal epithelial cells. Reproduction 134 123-135.

Cikos S, Bukovska A \& Koppel J 2007 Relative quantification of mRNA: comparison of methods currently used for real-time PCR data analysis. BMC Molecular Biology 8113.

Daniels R, Hall V \& Trounson AO 2000 Analysis of gene transcription in bovine nuclear transfer embryos reconstructed with granulosa cell nuclei. Biology of Reproduction 63 1034-1040.

Degrelle SA, Campion E, Cabau C, Piumi F, Reinaud P, Richard C, Renard JP \& Hue I 2005 Molecular evidence for a critical period in mural trophoblast development in bovine blastocysts. Developmental Biology $288448-460$.

Demmers KJ, Derecka K \& Flint A 2001 Trophoblast interferon and pregnancy. Reproduction 121 41-49.

Ealy AD, Larson SF, Liu L, Alexenko AP, Winkelman GL, Kubisch HM, Bixby JA \& Roberts RM 2001 Polymorphic forms of expressed bovine interferon- $\tau$ genes: relative transcript abundance during early placental development, promoter sequences of genes and biological activity of protein products. Endocrinology 142 2906-2915.

Feldman B, Poueymirou W, Papaioannou VE, DeChiara TM \& Goldfarb M 1995 Requirement of FGF-4 for postimplantation mouse development. Science 267 246-249.

Fischer-Brown AE, Lindsey BR, Ireland FA, Northey DL, Monson RL, Clark SG, Wheeler MB, Kesler DJ, Lane SJ, Weigel KA et al. 2004 Embryonic disc development and subsequent viability of cattle embryos following culture in two media under two oxygen concentrations. Reproduction, Fertility, and Development 16 787-793.

Gifford CA, Assiri AM, Satterfield MC, Spencer TE \& Ott TL 2008 Receptor transporter protein 4 (RTP4) in endometrium, ovary, and peripheral blood leukocytes of pregnant and cyclic ewes. Biology of Reproduction 79 518-524.

Haimovici F, Hill JA \& Anderson DJ 1991 The effects of soluble products of activated lymphocytes and macrophages on blastocyst implantation events in vitro. Biology of Reproduction 44 69-75.

Hernandez-Ledezma JJ, Sikes JD, Murphy CN, Watson AJ, Schultz GA \& Roberts RM 1992 Expression of bovine trophoblast interferon in conceptuses derived by in vitro techniques. Biology of Reproduction 47 374-380.

Hrabe DA, Grundker C, Herrmann BG, Kispert A \& Kirchner C 1995 Promotion of gastrulation by maternal growth factor in cultured rabbit blastocysts. Cell and Tissue Research 282 147-154.

Hue I, Renard JP \& Viebahn C 2001 Brachyury is expressed in gastrulating bovine embryos well ahead of implantation. Development Genes and Evolution 211 157-159.

Hughes M, Dobric N, Scott IC, Su L, Starovic M, St-Pierre B, Egan SE, Kingdom JC \& Cross JC 2004 The Hand1, Stra13 and Gcm1 transcription factors override FGF signaling to promote terminal differentiation of trophoblast stem cells. Developmental Biology 271 26-37.
Inskeep EK \& Dailey RA 2005 Embryonic death in cattle. Veterinary Clinics of North America. Food Animal Practice 21 437-461.

Itoh N \& Ornitz DM 2004 Evolution of the Fgf and Fgfr gene families. Trends in Genetics 20 563-569.

Itoh N \& Ornitz DM 2008 Functional evolutionary history of the mouse Fgf gene family. Developmental Dynamics 237 18-27.

Johnson DE, Lu J, Chen H, Werner S \& Williams LT 1991 The human fibroblast growth factor receptor genes: a common structural arrangement underlies the mechanisms for generating receptor forms that differ in their third immunoglobulin domain. Molecular and Cellular Biology 11 4627-4634.

Ka H, Jaeger LA, Johnson GA, Spencer TE \& Bazer FW 2001 Keratinocyte growth factor is up-regulated by estrogen in the porcine uterine endometrium and functions in trophectoderm cell proliferation and differentiation. Endocrinology 142 2303-2310.

Kim I, Moon S, Yu K, Kim U \& Koh GY 2001 A novel fibroblast growth factor receptor-5 preferentially expressed in the pancreas(1). Biochimica et Biophysica Acta 1518 152-156.

Komi-Kuramochi A, Kawano M, Oda Y, Asada M, Suzuki M, Oki J \& Imamura T 2005 Expression of fibroblast growth factors and their receptors during full-thickness skin wound healing in young and aged mice. Journal of Endocrinology 186 273-289.

Kubisch HM, Larson MA \& Roberts RM 1998 Relationship between age of blastocyst formation and interferon- $\tau$ secretion by in vitro-derived bovine embryos. Molecular Reproduction and Development 49 254-260.

Kubisch HM, Larson MA \& Kiesling DO 2001 Control of interferon- $\tau$ secretion by in vitro-derived bovine blastocysts during extended culture and outgrowth formation. Molecular Reproduction and Development 58 390-397.

Larionov A, Krause A \& Miller W 2005 A standard curve based method for relative real time PCR data processing. BMC Bioinformatics 662 .

Lazzari G, Wrenzycki C, Herrmann D, Duchi R, Kruip T, Niemann H \& Galli C 2002 Cellular and molecular deviations in bovine in vitroproduced embryos are related to the large offspring syndrome. Biology of Reproduction 67 767-775.

Lu W, Luo Y, Kan M \& McKeehan WL 1999 Fibroblast growth factor-10. A second candidate stromal to epithelial cell andromedin in prostate. Journal of Biological Chemistry 274 12827-12834.

Maddox-Hyttel P, Alexopoulos NI, Vajta G, Lewis I, Rogers P, Cann L, Callesen H, Tveden-Nyborg P \& Trounson A 2003 Immunohistochemical and ultrastructural characterization of the initial post-hatching development of bovine embryos. Reproduction 125 607-623.

Mann GE, Fray MD \& Lamming GE 2006 Effects of time of progesterone supplementation on embryo development and interferon- $\tau$ production in the cow. Veterinary Journal 171 500-503.

Michael DD, Alvarez IM, Ocon OM, Powell AM, Talbot NC, Johnson SE \& Ealy AD 2006 Fibroblast growth factor- 2 is expressed by the bovine uterus and stimulates interferon- $\tau$ production in bovine trophectoderm. Endocrinology 147 3571-3579.

Moreira F, Paula-Lopes FF, Hansen PJ, Badinga L \& Thatcher WW 2002 Effects of growth hormone and insulin-like growth factor-I on development of in vitro derived bovine embryos. Theriogenology $\mathbf{5 7}$ 895-907.

Ocon-Grove OM, Cooke FN, Alvarez IM, Johnson SE, Ott TL \& Ealy AD 2008 Ovine endometrial expression of fibroblast growth factor (FGF) 2 and conceptus expression of FGF receptors during early pregnancy. Domestic Animal Endocrinology 34 135-145.

Ornitz DM 2000 FGFs, heparan sulfate and FGFRs: complex interactions essential for development. BioEssays 22 108-112.

Ott TL, Yin J, Wiley AA, Kim HT, Gerami-Naini B, Spencer TE, Bartol FF, Burghardt RC \& Bazer FW 1998 Effects of the estrous cycle and early pregnancy on uterine expression of $\mathrm{Mx}$ protein in sheep (Ovis aries). Biology of Reproduction 59 784-794.

Paula-Lopes FF \& Hansen PJ 2002 Apoptosis is an adaptive response in bovine preimplantation embryos that facilitates survival after heat shock. Biochemical and Biophysical Research Communications 295 37-42.

Pfarrer C, Weise S, Berisha B, Schams D, Leiser R, Hoffmann B \& Schuler G 2006 Fibroblast growth factor (FGF)-1, FGF2, FGF7 and FGF receptors are uniformly expressed in trophoblast giant cells during restricted trophoblast invasion in cows. Placenta 27 758-770.

Powers CJ, McLeskey SW \& Wellstein A 2000 Fibroblast growth factors, their receptors and signaling. Endocrine-Related Cancer 7 165-197. 
Pru JK, Austin KJ, Haas AL \& Hansen TR 2001 Pregnancy and interferon- $\tau$ upregulate gene expression of members of the 1-8 family in the bovine uterus. Biology of Reproduction 65 1471-1480.

Rivera RM \& Hansen PJ 2001 Development of cultured bovine embryos after exposure to high temperatures in the physiological range. Reproduction 121 107-115.

Roberts RM 1991 Embryonic loss and conceptus interferon production. In Uterine and Embryonic Factors in Early Pregnancy, pp 21-31. Eds JF Strauss \& CR Lyttle. New York, NY: Plenum Press.

Roberts RM, Imakawa K, Niwano Y, Kazemi M, Malathy PV, Hansen TR, Glass AA \& Kronenberg LH 1989 Interferon-production by the preimplantation sheep embryo. Journal of Interferon Research 9 175-187.

Roberts RM, Ezashi T, Rosenfeld CS, Ealy AD \& Kubisch HM 2003 Evolution of the interferon tau genes and their promoters, and maternal-trophoblast interactions in control of their expression. Reproduction Supplement $61239-251$.

Roberts RM, Ezashi T \& Das P 2004 Trophoblast gene expression: transcription factors in the specification of early trophoblast. Reproductive Biology and Endocrinology 247.

Robinson RS, Fray MD, Wathes DC, Lamming GE \& Mann GE 2006 In vivo expression of interferon tau mRNA by the embryonic trophoblast and uterine concentrations of interferon tau protein during early pregnancy in the cow. Molecular Reproduction and Development 73 470-474.

Rodina TM, Cooke FN, Hansen PJ \& Ealy AD 2008 Oxygen tension and medium type actions on blastocyst development and interferon- $\tau$ secretion in cattle. Animal Reproduction Science [in press]. DOI: 10.1016/j.anireprosci.2008.02.014.

Sartori R, Souza AH, Guenther JN, Caraviello DZ, Geiger LN, Schenk JL \& Wiltbank MC 2004 Fertilization rate and embryo quality in superovulated Holstein heifers artificially inseminated with X-sorted or unsorted sperm. Animal Reproduction Science 1 86-90.

Shimada A, Nakano H, Takahashi T, Imai K \& Hashizume K 2001 Isolation and characterization of a bovine blastocyst-derived trophoblastic cell line, BT-1: development of a culture system in the absence of feeder cell. Placenta 22 652-662.

Sleeman M, Fraser J, McDonald M, Yuan S, White D, Grandison P, Kumble K, Watson JD \& Murison JG 2001 Identification of a new fibroblast growth factor receptor, FGFR5. Gene 271 171-182.

Spencer TE, Ott TL \& Bazer FW 1998 Expression of interferon regulatory factors one and two in the ovine endometrium: effects of pregnancy and ovine interferon tau. Biology of Reproduction 58 1154-1162.

Spencer TE, Burghardt RC, Johnson GA \& Bazer FW 2004 Conceptus signals for establishment and maintenance of pregnancy. Animal Reproduction Science 82-83 537-550.
Talbot NC, Caperna TJ, Edwards JL, Garrett W, Wells KD \& Ealy AD 2000 Bovine blastocyst-derived trophectoderm and endoderm cell cultures: interferon tau and transferrin expression as respective in vitro markers. Biology of Reproduction 62 235-247.

Talbot NC, Powell AM, Camp M \& Ealy AD 2007 Establishment of a bovine blastocyst-derived cell line collection for the comparative analysis of embryos created in vivo and by in vitro fertilization, somatic cell nuclear transfer, or parthenogenetic activation. In Vitro Cellular \& Developmental Biology. Animal 43 59-71.

Tanaka S, Kunath T, Hadjantonakis AK, Nagy A \& Rossant J 1998 Promotion of trophoblast stem cell proliferation by FGF4. Science $\mathbf{2 8 2}$ 2072-2075.

Taniguchi F, Harada T, Yoshida S, Iwabe T, Onohara Y, Tanikawa M \& Terakawa $\mathbf{N} 1998$ Paracrine effects of bFGF and KGF on the process of mouse blastocyst implantation. Molecular Reproduction and Development $\mathbf{5 0}$ 54-62.

Teixeira MG, Austin KJ, Perry DJ, Dooley VD, Johnson GA, Francis BR \& Hansen TR 1997 Bovine granulocyte chemotactic protein-2 is secreted by the endometrium in response to interferon-tau (IFN-tau). Endocrine 6 31-37.

Thatcher WW, Staples CR \& Danet-Desnoyers G 1994 Embryo health and mortality in sheep and cattle. Journal of Animal Science 72 16-30.

Thatcher WW, Guzeloglu A, Mattos R, Binelli M, Hansen TR \& Pru JK 2001 Uterine-conceptus interactions and reproductive failure in cattle. Journal of Reproduction and Fertility 56 1435-1450.

Umemori H, Linhoff MW, Ornitz DM \& Sanes JR 2004 FGF22 and its close relatives are presynaptic organizing molecules in the mammalian brain. Cell 118 257-270.

Wang BT \& Goff AK 2002 Interferon-tau stimulates secretion of macrophage migration inhibitory factor from bovine endometrial epithelial cells. Biology of Reproduction 66 118-119.

Werner S, Duan DS, de Vries C, Peters KG, Johnson DE \& Williams LT 1992 Differential splicing in the extracellular region of fibroblast growth factor receptor 1 generates receptor variants with different ligand-binding specificities. Molecular and Cellular Biology 12 82-88.

Wilkinson DG, Bhatt S \& McMahon AP 1989 Expression pattern of the FGFrelated proto-oncogene int-2 suggests multiple roles in fetal development. Development 105 131-136.

Received 18 September 2008

First decision 8 October 2008

Accepted 7 November 2008 